\title{
VARIATION OF ABUNDANCE AND DEMOGRAPHIC STRUCTURE OF THE INTRODUCED PUMPKINSEED, LEPOMIS GIBBOSUS (ACTINOPTERYGII: PERCIFORMES: CENTRARCHIDAE), IN RELATION TO LITTORAL HABITATS AND WATER BODY USE
}

\author{
Eliza P. UZUNOVA ${ }^{1 *}$, Martina GEORGIEVA ${ }^{1}$, Milena N. PAVLOVA², Slavi STUDENKOV ${ }^{1}$, \\ and Vasil POPOV ${ }^{2}$
}

\author{
${ }^{1}$ Division of General and Applied Hydrobiology, Faculty of Biology, Sofia University, Sofia, Bulgaria \\ ${ }^{2}$ Institute of Biodiversity and Ecosystem Research, BAS, Sofia, Bulgaria
}

Uzunova E.P., Georgieva M., Pavlova M.N., Studenkov S., Popov V. 2012. Variation of abundance and demographic structure of the introduced pumpkinseed, Lepomis gibbosus (Actinopterygii: Perciformes: Centrarchidae), in relation to littoral habitats and water body use. Acta Ichthyol. Piscat. 42 (2): 121-130.

Background. The pumpkinseed, Lepomis gibbosus (L.), is one of 23 introduced fish species in Bulgarian freshwaters. With this study we attempt to contribute to clarifying the factors that effect pumpkinseed abundance and demographic structure in water bodies differing in macro- and microhabitat parameters.

Materials and methods. Fish were collected during the breeding period of pumpkinseed (May-June 2010) by minnow traps arranged in 31 sites in the littoral zone of 13 fresh water bodies (former- and active sand-pit lakes, reservoirs, adaptive ponds of refineries). Demographic structure (length and age) and abundance (Catch Per Unit Effort; $\mathrm{CPUE}_{N}$; fish per trap per hour) of pumpkinseeds from different sites were compared to provide information about ecological requirements of this species.

Results. L. gibbosus dominated at 24 sites and comprised $86.7 \%$ of all fish caught. The mean pumpkinseed abundance was $6.35 \pm 7.2$ fish per trap per hour (mean \pm SD). Pumpkinseeds were most numerous in the littoral zones of the former sand-pit lakes, where pumpkinseed's CPUE ${ }_{N}$ achieved values of 20 fish per trap per hour. Water body use had a significant effect on pumpkinseed abundance and the statistical analyses revealed that the littoral zones in the active sand-pit lakes were characterized by the lowest number of pumpkinseeds than the other types. Microhabitat parameters such as silt and sand bottom substrate also significantly affected pumpkinseeds abundance, size, and age, while gravel significantly affected body length but not abundance and age. Aquatic vegetation also had a significant impact on the abundance and at sites with dense vegetation pumpkinseeds were more abundant than at the sites with sparse vegetation. At the sites where piscivore fish occurred, the mean length and mean age of pumpkinseed were lower.

Conclusion. Human activities facilitate establishment of the pumpkinseed population, mainly by extending suitable breeding places for pumpkinseed and eliminating its natural competitors and predators. Some parameters as sand or silt bottoms in littoral area and dense submerged vegetation may use as indicator of suitable conditions for pumpkinseed.

Keywords: Lepomis gibbosus, abundance, age-size structure, environmental parameters, water body use, Bulgaria

\section{INTRODUCTION}

The pumpkinseed, Lepomis gibbous (L.), is a telling example of successful fish introduction into the majority of European inland bodies of water (Crivelli and Mestre 1988, Holčik 1991, Welcomme 1991, Tomeček et al. 2007). The native environment of this species is being affected by the warm climate of eastern North America (Scott and Crossman 1973). It is thought that pumpkinseed was first imported around 1880 from Canada (García-Berthou et al. 2005). Initially, L. gibbosus was released, as an ornamental fish, to garden ponds and aquaria (Copp et al. 2005a).
Later pumpkinseed was spread by re-stocking material of common carp (Tandon 1976). Nowadays, this species is widely dispersed in Central and Western Europe (Welcomme 1991), as well as in Iberian and Balkan Peninsulas (Elvira and Almodóvar 2001, Economidis et al. 2000). In northern areas, pumpkinseeds were found to be abundant only in artificial- or heavily disturbed water bodies (van Kleef et al. 2008).

The distribution, growth, and feeding behaviour of pumpkinseeds are subject to profound analyses, mainly with aim to assess the potential impact of this alien

\footnotetext{
${ }^{*}$ Correspondence: Dr Eliza Uzunova, Division of General and Applied Hydrobiology, Faculty of Biology, Sofia University, Sofia, Bulgaria, phone: +039 887708957; e-mail: e_uzunova@abv.bg.
} 
species on native fish assemblages and the aquatic ecosystem as a whole (Crivelli and Mestre 1988, Fox and Crivelli 2001, Copp et al. 2004, Klaar et al. 2004, Villeneuve et al. 2005, Copp and Fox 2007, Nikolova et al. 2009). It was found that in most of the European ecosystems where pumpkinseeds have been introduced they influenced directly or indirectly native species through competition for food and predation on fish eggs and endemic molluscs (García-Berthou and MorenoAmich 2000, Copp et al. 2005b), zooplankton (Brabrand and Saltveit 1989), and as well as macroinvertebrates (van Kleef et al. 2008, Nikolova et al. 2009).

In Bulgaria, pumpkinseed has been known since the mid-1920s when it was discovered in marshes along the Danube River (Drensky 1923). It is thought that the River Danube played a key role in pumpkinseed distribution, not only in Bulgaria, but also throughout Europe (Marinov 1966). Nearly 40 years later, several new populations of pumpkinseed were reported in Bulgarian waters - mainly in tributaries and floodplain areas along the Danube River (Bulgurkov 1958, Karapetkova 1972, Karapetkova and Undzian 1988) and in some lowland reservoirs (Karapetkova 1972). Pumpkinseeds were not found in the river mouths of the Black Sea, except in the River Kamchja (Vassilev 1999). The current information about distribution and abundance of pumpkinseed in Bulgarian water bodies is scarce (Uzunova et al. 2008, Nikolova et al. 2009).

One of the key factors responsible for successful colonization of non-native habitats by pumpkinseeds are the flexible habitat requirements of this species (Klaar et al. 2004, Fox et al. 2007, Cucherousset et al. 2009). A high degree of variation in pumpkinseed's population parameters (growth rate, reproduction, abundance, size, and age structure) can be a side effect of macro- and microhabitat characteristics and biotic conditions as well (food availability, predation, and food competition). It is considered that humans are not only the main vector in the introduction and dispersal of pumpkinseed (Copp et al. 2005a, García-Berthou et al. 2005, Tomeček et al. 2007), but even facilitate invasion process by alteration of water body habitats and water quality (van Kleef et al. 2008). However, it has remained difficult to isolate mechanisms influencing pumpkinseed's population parameters. From a practical point of view, it would be very helpful to find the combination of those environmental factors responsible for success in the growing range and increased abundance of pumpkinseed and, on this basis, to develop and implement programs directed to promote the control of expansion of the invaders (Ricciardi and Rasmussen 1998, Kolar and Lodge 2001, Gozlan and Newton 2009, Panov et al. 2009, Gozlan et al. 2010).

The aim of this study was to improve our understanding of how biotic- and abiotic parameters as well as anthropogenic factors of investigated bodies of water interact with basic population parameters of non-native pumpkinseed. Specific research objectives of the study include: document the distribution, relative abundance, size, and age composition of L. gibbosus in the littoral zones of different type of water bodies in Bulgaria; evaluate relations between relative pumpkinseed abundance, age, and size and environmental variables characterised macro and microhabitats. We selected 13 bodies of water-differing in their origin, use, water quality, size, depth, and the microhabitat characteristics of their littoral zones-for the investigation of the above-mentioned parameters and relations.

\section{MATERIAL AND METHODS}

Study design. Thirteen artificial, semi-artificial, and natural bodies of water were surveyed in 2010 in order to assess the pumpkinseed abundance, size, and age structure. According to their specific management aims of use, water bodies were divided into five main categories: $1=$ active sand-pit lakes $(n=2), 2=$ former sand-pit lakes $(n=4)$, $3=$ reservoirs for cage aquaculture $(n=2), 4=$ reservoirs for water supply (industrial and irrigation) $(n=3), 5=$ waste waters deposition (adaptive ponds of refineries) $(n=2)$. All water bodies are used for recreational fishing. Macrohabitat parameters (maximum water depth, surface area, altitude) of the investigated bodies of water are shown in Table 1. Thirty-one survey sites located along the shoreline of the water bodies were chosen to represent a range of littoral habitats with variable degree of structural complexity. The selected sites were representative for the particular water body. Sampling was conducted during the period between the 10 May and 30 June 2010 that coincided with pumpkinseed breeding season.

Sampling protocol. Each study site was sampled with minnow trap-nets to estimate the relative abundance of pumpkinseed and other small-bodied fish inhabiting the littoral zone. Minnow traps were chosen because they could be set in almost any lake or habitat type (MacRae and Jackson 2006). We used commercially available Gee minnow traps with an opening diameter of 6-7 $\mathrm{cm}$ and a mesh size of $0.45 \mathrm{~cm}$. Traps were baited with a dry trout feed and were set for $1 \mathrm{~h}$ during the sunny days between 0900 and $1600 \mathrm{~h}$. The trap-nets were fixed to the shore with $5 \mathrm{~m}$ and $2.5 \mathrm{~m}$ cords in chessboard pattern. They were set along the coast, $2.5 \mathrm{~m}$ from each other. The number of traps used depended on the site length and varied from 15 to 20 per site. Collected fish were identified in situ (Kottelat and Freyhoff 2007). Pumpkinseeds were euthanized using clove oil, preserved in $10 \%$ formalin, then rinsed in water before being stored in $70 \%$ ethanol until analysed. Native fishes were released at the site after counting.

Habitat assessment. The following biotic-, and physical habitat variables at two transects parallel to the shore (between 1 and $5 \mathrm{~m}$ off the coast) were measured or scored: water depth, bottom substrate type, bank slope, percent submerged aquatic vegetation, type of coastal vegetation, electro-conductivity, oxygen saturation, dissolved oxygen, $\mathrm{pH}$, and water temperature. At each study site, the physical and chemical parameters were measured 30 min after removal of the traps. Mean water depth and 
substrate composition (in \% of section area) were visually estimated at $1 \mathrm{~m}$ intervals at each transect and categorised as follows: silt $(<0.06 \mathrm{~cm})$, sand $(0.06-0.2 \mathrm{~cm})$, gravel $(0.2-4.0 \mathrm{~cm})$, boulders $(>25 \mathrm{~cm})$. Aquatic vegetation was scored $1,2,3$, or $4(1=$ missing, $2=$ sparse, $3=$ intermediate, or $4=$ dense). Coastal vegetation was described as: 1 = reed-belt, 2 = mixed broad-leaved, or 3 = grass. Bank slope received score 1 or $2(1=$ steep, $2=$ gently inclined). Presence or absence of piscivore fish (= predators) was described in two categories: $1=$ present and $2=$ absent. Electro-conductivity $\left(\mu \mathrm{S} \cdot \mathrm{cm}^{-1}\right)$; oxygen saturation $(\mathrm{ppm})$, dissolved oxygen $\left(\mathrm{mg} \cdot \mathrm{L}^{-1}\right) ; \mathrm{pH}$ and water temperature $\left({ }^{\circ} \mathrm{C}\right)$ were measured in situ using a WTW Oxi 330i, WTW pH 330i and HI 98311.

Fish analyses. A total of 1950 pumpkinseed specimens were collected and their total length (TL) was measured to the nearest $0.01 \mathrm{~cm}$. Fish age was determined from scales removed from below the anterior part of the dorsal fin. Scale measurements were made on the oral radius. The ageing study was conducted using a microfilm reader at magnification of $17.5 \times$. Two investigators independently determined the age of fish. Age was confirmed if the percentage of disagreement was below 10 percent. For scales with higher discrepancies, additional measurements were made until agreement was reached.

Data analyses. Catch per unit effort (CPUE) was used as a measure of fish abundance. The $\mathrm{CPUE}_{N}$ was calculated as the number of fish caught per trap per hour [FTH]. Analysis of variance (one-way ANOVA, $P<0.05$ ) was applied to test the effect of environmental characteristics on the pumpkinseed's biological parameters and-in case of significance-Tukey post hoc tests were carried out to test for differences in mean values between the habitat types. Prior to analysis, all variables including fish abundance, habitat, and water quality measurements were evaluated for normality (normal probability plot or Chisquared analysis). Those that significantly departed from a reasonable normal distribution were $\log (x+1)$ (continuous variables) or arcsine square root $\left(x \cdot 100^{-1}\right)$ transformed (percentages). Relations between pumpkinseeds abundance, size, age, and abundance of other fish species were tested using simple linear regression, following log $(x+1)$ transformations of the raw data. For statistical analysis, the programs Statistica 7.0 (StatSoft ${ }^{\mathcal{C}}$ Inc.) and XLStat (Addinsoft) were used.

\section{RESULTS}

A total of 11 fish species belonging to 4 families were caught in littoral zones of the investigated water bodies. L. gibbosus has been recorded at 26 sites, while 5 sites, located at the natural Lake Varnensko and the active sandpit Lake Chepinci were devoid of pumpkinseeds. Actually, at two sites (CHP2 and VE), situated in the mentioned above water bodies we did not succeed in catching any fish. As a whole, species diversity of all investigated littoral zones was relatively low and varied between 1 and 4 species (Fig. 1). L. gibbosus dominated at 24 sites and constituted $86.7 \%$ of all fish caught. Pumpkinseed abundance and total abundance varied broadly from site to site (from 0 to 25.4 and from 0 to 37.1 FTH, respectively) (Fig. 2). The mean pumpkinseed abundance was $6.35 \pm 7.2$ FTH (mean \pm standard deviation). The highest total abundance (37.4 FTH) was recorded at site located in Sopot Reservoir, followed by the former sand-pit lakes Svetovrachane and Negovan (Fig. 2). The lowest total abundance was observed at sites situated

Table 1

Principal chacteristics of the Bulgarian bodies of water investigated for the abundance of pumpkinseed, Lepomis gibbosus L.

\begin{tabular}{|c|c|c|c|c|c|c|c|}
\hline $\begin{array}{l}\text { Name of water } \\
\text { body }\end{array}$ & $N$ & $\begin{array}{l}\text { Investigated sites } \\
\text { (codes) }\end{array}$ & $\begin{array}{l}\text { Geographic } \\
\text { coordinates }\end{array}$ & $\begin{array}{l}\text { Type of water body } \\
\text { and use }\end{array}$ & $\begin{array}{c}\text { Surface } \\
\text { area } \\
{\left[\mathrm{km}^{2}\right]}\end{array}$ & $\begin{array}{c}\text { Maximum } \\
\text { depth } \\
{[\mathrm{m}]}\end{array}$ & $\begin{array}{l}\text { Altitude } \\
{[\mathrm{m}]}\end{array}$ \\
\hline Dolni Bogrov & 4 & DB1-DB4 & $42^{\circ} 42^{\prime} \mathrm{N}, 23^{\circ} 28^{\prime} \mathrm{E}$ & Former sand-pit lake & 0.37 & 4.5 & 550 \\
\hline Negovan & 2 & NEG1-NEG2 & $42^{\circ} 46^{\prime} \mathrm{N}, 23^{\circ} 23^{\prime} \mathrm{E}$ & Former sand-pit lake & 0.1 & 2.8 & 550 \\
\hline Svetovrachene & 4 & SV1-SV4 & $42^{\circ} 46^{\prime} \mathrm{N}, 23^{\circ} 23^{\prime} \mathrm{E}$ & Former sand-pit lake & 0.04 & 2.2 & 550 \\
\hline Chepintzi & 4 & CHP1-CHP4 & $42^{\circ} 44^{\prime} \mathrm{N}, 23^{\circ} 25^{\prime} \mathrm{E}$ & Active sand-pit lake & 0.24 & 19 & 560 \\
\hline Chelopechene & 2 & CHL1-CHL2 & $42^{\circ} 43^{\prime} \mathrm{N}, 23^{\circ} 27^{\prime} \mathrm{E}$ & Active sand-pit lake & 0.82 & 15 & 550 \\
\hline Kurdjali & 2 & $\mathrm{KR} 1-\mathrm{KR} 2$ & $41^{\circ} 38^{\prime} \mathrm{N}, 25^{\circ} 18^{\prime} \mathrm{E}$ & $\begin{array}{l}\text { Reservoir; cage } \\
\text { aquaculture }\end{array}$ & 16.07 & 65 & 340 \\
\hline $\begin{array}{l}\text { Pleven } \\
\text { ("Plama" refinery) }\end{array}$ & 2 & PL1-PL2 & $43^{\circ} 24^{\prime} \mathrm{N}, 24^{\circ} 30^{\prime} \mathrm{E}$ & Waste water discharge & 0.05 & 3 & 70 \\
\hline Jasen & 2 & JS1-JS2 & $43^{\circ} 24^{\prime} \mathrm{N}, 24^{\circ} 30^{\prime} \mathrm{E}$ & Waste water discharge & 0.03 & 2.8 & 69 \\
\hline Dospat & 3 & DS1-DS3 & $41^{\circ} 38^{\prime} \mathrm{N}, 24^{\circ} 09^{\prime} \mathrm{E}$ & $\begin{array}{l}\text { Reservoir; } \\
\text { cage aquaculture }\end{array}$ & 22 & 74 & 1220 \\
\hline Ognjanovo & 2 & OG1-OG2 & $42^{\circ} 36^{\prime} \mathrm{N}, 23^{\circ} 44^{\prime} \mathrm{E}$ & Reservoir; water supply & 4.16 & 47 & 630 \\
\hline Marchaevo & 2 & MR1-MR2 & $42^{\circ} 35^{\prime} \mathrm{N}, 23^{\circ} 09^{\prime} \mathrm{E}$ & Reservoir; water supply & 0.01 & 3.2 & 770 \\
\hline Sopot & 1 & SOP & $42^{\circ} 59^{\prime} \mathrm{N}, 24^{\circ} 28^{\prime} \mathrm{E}$ & Reservoir; water supply & 14 & 28 & 400 \\
\hline Varnensko & 1 & $\mathrm{VE}$ & $43^{\circ} 11^{\prime} \mathrm{N}, 27^{\circ} 46^{\prime} \mathrm{E}$ & $\begin{array}{l}\text { Sea-coast lake; } \\
\text { waste water discharge }\end{array}$ & 19 & 19 & 0 \\
\hline
\end{tabular}

$N=$ number of sites investigated. 
at active sand-pit lakes and Kurdjali Reservoir (CHP3, CHP4, CHL1, KR1, and KR2). Pumpkinseeds were the most numerous in the littoral zones of the former sand-pit lakes Negovan and Svetovrachane, where pumpkinseed's $\mathrm{CPUE}_{\mathrm{N}}$ achieved values of $20 \mathrm{FTH}$. The sites with the lowest abundance were situated in the Kardjali Reservoir, active sand-pit lakes (Chelopechene and Chepintzi) and micro-reservoir Marchaevo. Two piscivore fishEuropean perch, Perca fluviatilis L., and pike perch, Sander lucioperca (L.) - were caught at 11 of the 31 study sites. Total piscivore abundance range from 0.1 to 24.8 FTH. In total, perch made up $97.1 \%$ of the total piscivores caught while pike perch made up only $2.9 \%$. Bitterling, Rhodeus sericeus (Pallas, 1776), dominated at only one site (CHL1), but with very low relative abundance (1.0 FTH). One another exotic fish species, stone moroko, Pseudorasbora parva (Temminck et Schlegel, 1842), was found at five sites. The least frequently found $(2.3 \%)$ and least abundant $(<0.1 \%)$ species that composed the littoral ichthyofauna in the investigated sites were: rudd, Scardinius erythrophthalmus (L.); common carp,
Cyprinus carpio L.; Prussian carp, Carassius gibelio (Bloch, 1782); tench, Tinca tinca (L.); bleak, Alburnus alburnus (L.); and weatherfish, Misgurnus fossilis (L.).

The age of collected pumpkinseed varied significantly between sites and water bodies from $0+$ to $4+$ (Fig. 3). The most numerous were fish at age $1+$ and $2+$. The highest mean pumpkinseed's age was recorded at sites in lake for waste-water deposition (JS1 and JS2). In Sopot Reservoir, all captured pumpkinseeds were at age $1+$. The mean length (TL) of pumpkinseeds ranged from 39 through $82 \mathrm{~mm}$. Larger pumpkinseeds were found at sites located in the big reservoirs: Kardjali, Dospat, and Ognjanovo. The biggest specimen $(120 \mathrm{~mm})$ was caught at the site located in Dospat Reservoir (DOS3) and the smallest in Sopot Reservoir (Fig. 4).

Analysis of the effect of different macro- and microhabitat environmental parameters on pumpkinseed's abundance showed following relations (Tables 2 and 3). The majority of macrohabitat parameters did not affect any of population characteristics (Table 2). Only the type of water body had a significant effect on pumpkinseed

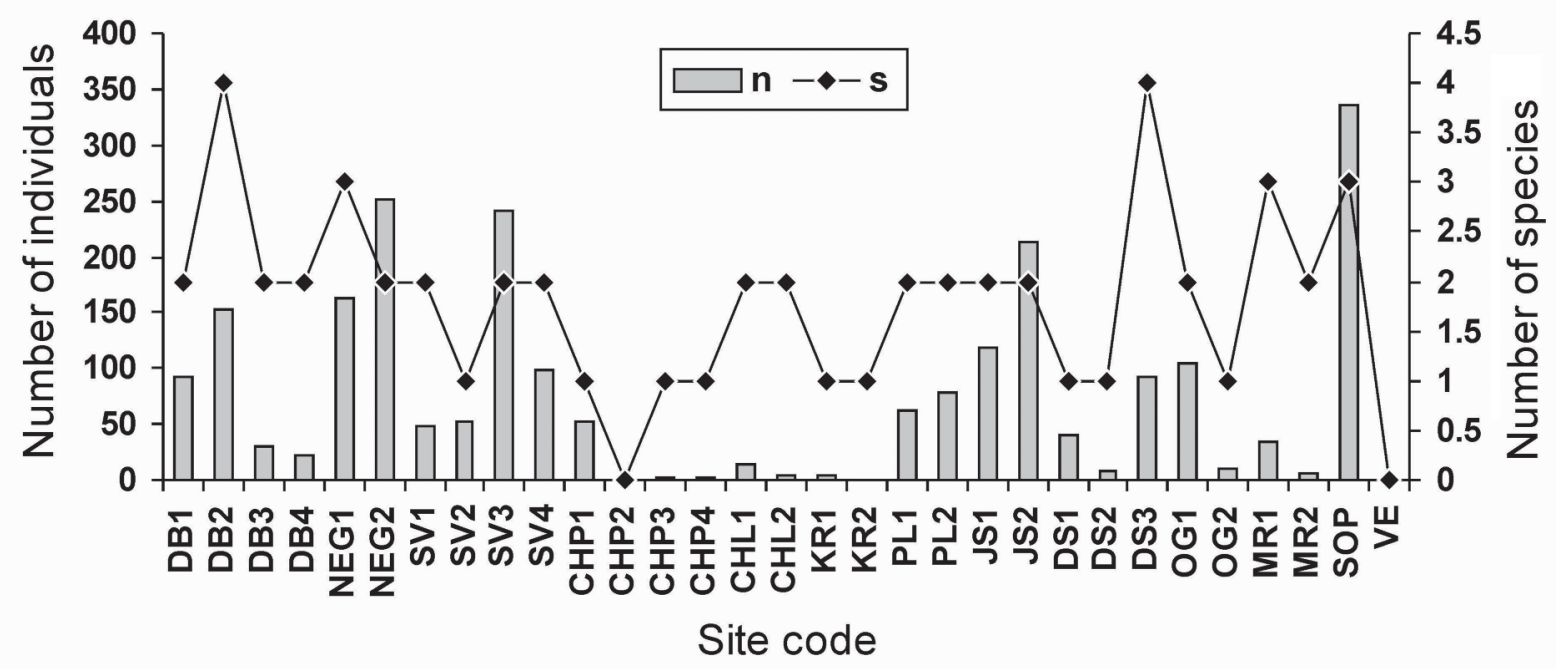

Fig. 1. Distribution of number of fish individuals $(n)$ and number of fish species $(s)$ at each site within May-June 2010

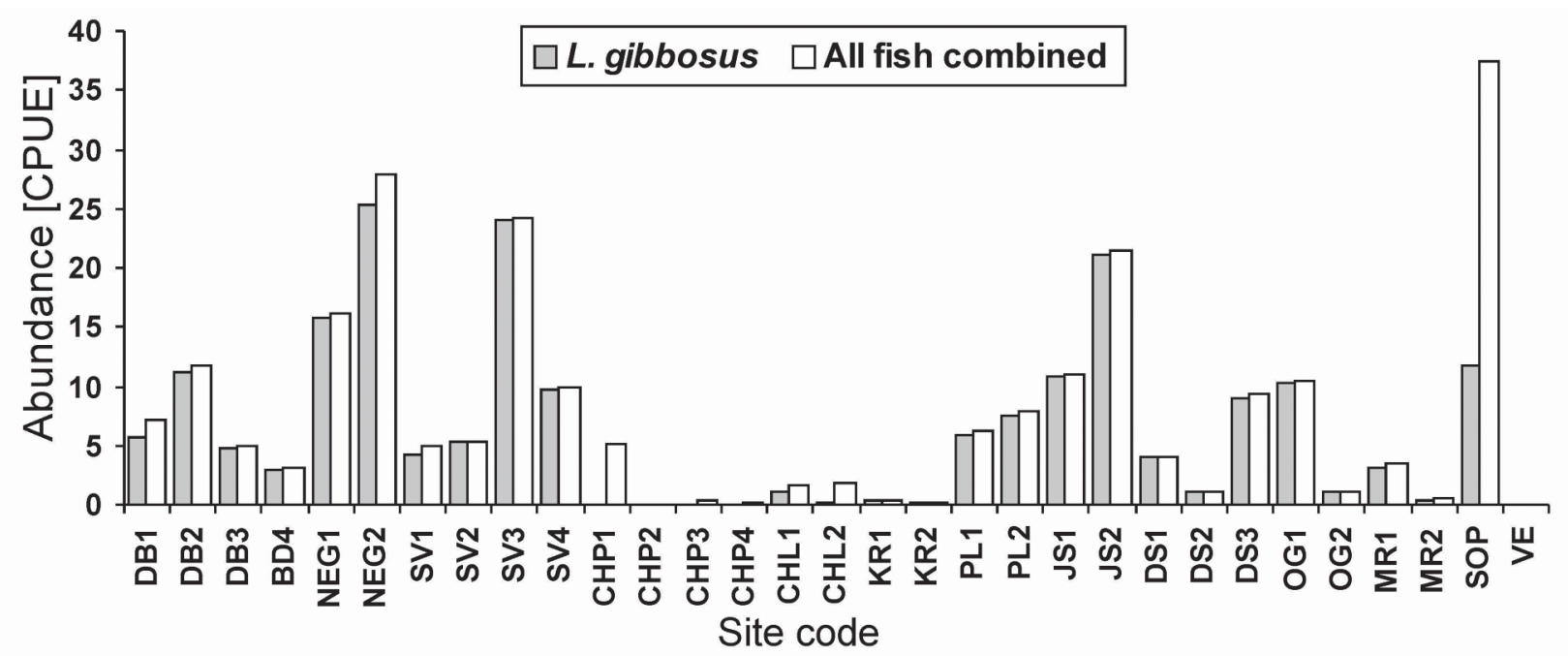

Fig. 2. Abundance $\left(\mathrm{CPUE}_{\mathrm{N}}=\right.$ catch per unit effort $)$ at individual sites for Lepomis gibbosus and all fish species combined (CPUE $=$ number of fish per trap per hour) 
abundance and HDS test revealed that the littoral zones in the active sand-pit lakes, were characterized by the lowest number of pumpkinseeds than the other types of water bodies (Tukey's HSD, to all four types $P<0.05$ ) (Fig. 5). Microhabitat parameters such as silt and sand bottom substrate also significantly affected pumpkinseeds abundance, size and age, while gravel significantly affected body length but not abundance and age (Table 3). Mean pumpkinseed age was significantly different only for the pair comparisons of former and active sand pit lakes (Tukey HSD, $P<0.001$ ) (Fig. 6). Pumpkinseeds with the lowest mean lengths were found in the active sand-pit lakes (Tukey HSD, to 2, 3, and 4 water body type $P<0.05$ ) (Fig. 7). Aquatic vegetation also had a significant impact on the abundance and in sites with dense vegetation pumpkinseeds were more abundant than the sites with sparse vegetation (Tukey HSD, $P=0.008$ ) (Fig. 8). The presence of predator fishes was a significant factor influencing pumpkinseed's mean length (ANOVA, $F=8.09, P=0.008$ ). At the sites where piscivore fish occurred, the mean length and mean age of pumpkinseed were lower (ANOVA, $F=8.09$, $P=0.008 ; F=10.4, P=0.003$ ).

There was a significant relation, best described by linear regression, between pumpkinseed abundance and species richness (Fig. 9). The regression line shows that the abundance of pumpkinseeds increasing with an increase of the number of fish species in the littoral zone $\left(r^{2}=0.4612, P=0.0003\right)$. There were no significant correlations between total piscivore or individual piscivore species abundance and pumpkinseed abundance.

\section{DISCUSSION}

The observed wide distribution of pumpkinseed in Bulgarian water bodies did not differ significantly from the situation in the majority of European countries, where pumpkinseed can be found in a diverse range of water body types including natural and semi-natural lakes, small wetlands, reservoirs, marshes, fish ponds, and rivers (Klaar et al. 2004, Oliva-Paterna et al. 2005, Tomeček et al. 2007). And while the existence of pumpkinseeds is not surprising for small water bodies located in a proximity to urban areas, it is unusual for high mountain reservoirs with low annual temperatures and deep waters, such as Dospat Reservoir. The extremely high abundance of the species in those waters can possibly be attributed to the operation of intensive cage aquaculture facilities during recent years, which steadily leads to high levels of eutrophication of the basic oligotrophic artificial lakes.

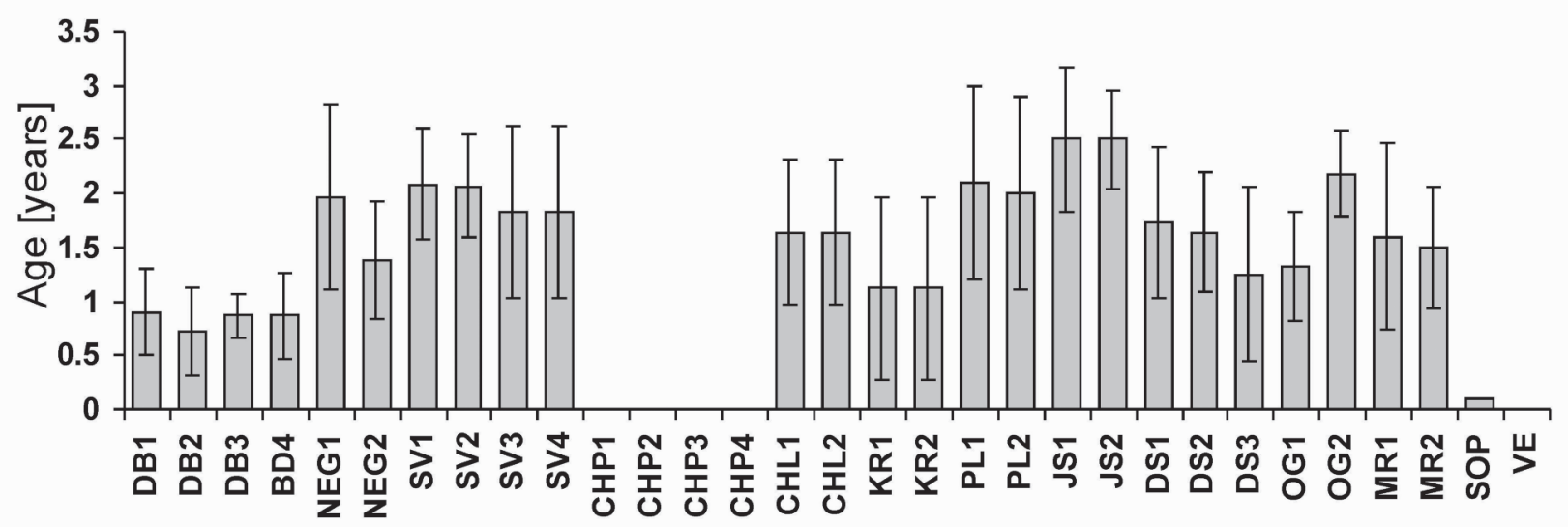

Site code

Fig. 3. Mean age of Lepomis gibbosus at individual sites within May-June 2010

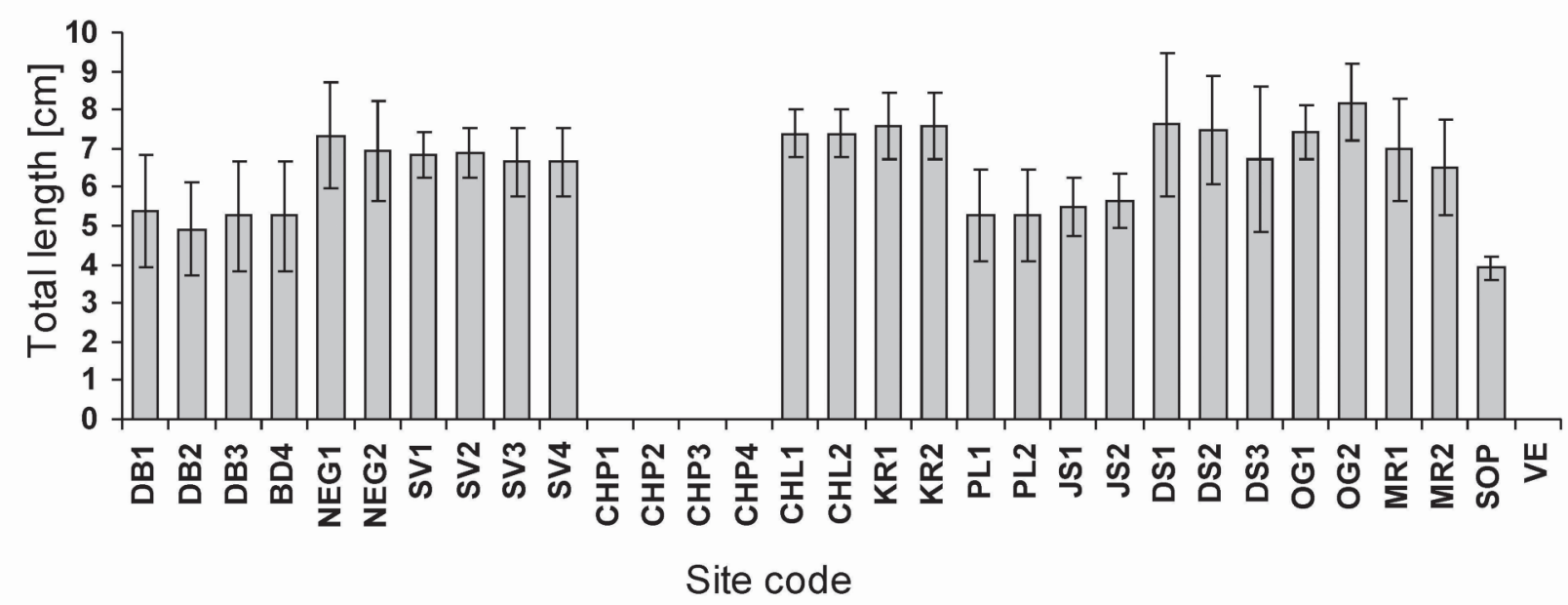

Fig. 4. Mean total length of Lepomis gibbosus at individual sites within May-June 2010 
Pumpkinseed was introduced in these reservoirs as a bait fish or with restocking material. The concern in this case is that most of the water bodies in which cage aquacultures are placed in Bulgaria at the moment are part of or on the boundaries of NATURA 2000 areas, and the invasion of exotic species is extremely undesirable. In contrast with Dospat Reservoir, in other investigated water bodies such as reservoirs with irrigation purposes and active sandpit lakes, the recorded abundance of pumpkinseed was relatively low. The observed low abundance might be explained by the fluctuating hydrological conditions in connection with irrigation and sand and gravel acquisition.

In most cases, the littoral zones of artificial and natural water bodies are strongly influenced by human activities. It is considered that habitat alteration by humans may be responsible for the establishment of some invasive fish species in Mediterranean-type streams and the increase in species invasiveness (Vila-Gispert et al. 2005, Almeida et al. 2009). Van Kleef et al. (2008) found that pumpkinseed is more abundant in fishing and moorland ponds, urban waters, and also water basins from which organic sediments, macrophytes, or inert materials have been obtained. Analysis of the relation between water body management and pumpkinseed abundance confirms the role of humans in the growth of pumpkinseed populations. The pumpkinseed abundance correlated positively with sandy and silty bottom substrate and this observation was in accordance with the reported pumpkinseed preference for constructing their nests more frequently on the sandy type of substrate (Danylchuk and Fox 1994). The other parameter that has a positive influence on pumpkinseed abundance is the density of submersed water vegetation. Without statistical conformation we observed that in the sites where the coastal vegetation is grass or reed, the species was more abundant. This is most likely due to the better exposure to the sun of sites surrounded by grass and numerous shelters in the reed belt. The lack of a statistically significant influence of predators on pumpkinseed abundance is not expected based on our observation that pumpkinseed was the most frequently found prey in the perch pike's stomach (personal observation, unpublished).

It might be concluded that former sand-pit lakes give optimal opportunities for pumpkinseed breeding and growth. There are several prerequisites facilitating this process.

Effects of macro habitat parameters on the abundance, body size, and age of pumpkinseed,

Table 2 Lepomis gibbosus L. in Bulgaria

\begin{tabular}{|c|c|c|c|c|c|c|c|c|}
\hline & \multirow{3}{*}{ Macrohabitat parameters } & & \multicolumn{6}{|c|}{ Dependent variables } \\
\hline & & & \multicolumn{2}{|c|}{ Abundance } & \multicolumn{2}{|c|}{ Size } & \multicolumn{2}{|c|}{ Age } \\
\hline & & $\mathrm{df}$ & $F$ & $P$ & $F$ & $P$ & $F$ & $P$ \\
\hline \multirow{9}{*}{ 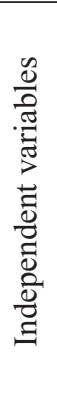 } & Water body use & 4.26 & 8.92 & $0.0001^{\mathrm{c}}$ & 6.53 & $0.0008^{\mathrm{c}}$ & 2.85 & $0.04^{\mathrm{a}}$ \\
\hline & Surface area & 1.29 & 1.09 & 0.3 & 0.18 & 0.68 & 0.41 & 0.52 \\
\hline & Maximum depth & 1.29 & 2.9 & 0.09 & 0.41 & 0.52 & 0.12 & 0.73 \\
\hline & Altitude & 1.29 & 0.18 & 0.67 & 1.27 & 0.27 & 0.03 & 0.85 \\
\hline & Dissolve oxygen & 1.29 & 3.26 & 0.08 & 3.63 & 0.07 & 3.28 & 0.08 \\
\hline & Oxygen saturation & 1.29 & 0.35 & 0.55 & 3.34 & 0.08 & 0.82 & 0.19 \\
\hline & $\mathrm{pH}$ & 1.29 & 1.73 & 0.2 & 1.51 & 0.23 & 1.55 & 0.22 \\
\hline & Temperature & 1.29 & 4.84 & 0.06 & 0.71 & 0.4 & 2.52 & 0.12 \\
\hline & Electro conductivity & 1.29 & 0.08 & 0.78 & 1.17 & 0.28 & 3.44 & 0.08 \\
\hline
\end{tabular}

a, b, c Significant at $P \leq 0.05,0.01$, and 0.001 , respectively; $\mathrm{df}=$ degrees of freedom.

Effects of microhabitat parameters on the abundance, body size, and age of pumpkinseed,

Table 3

Lepomis gibbosus L. in Bulgaria

\begin{tabular}{|c|c|c|c|c|c|c|c|c|}
\hline & \multirow{3}{*}{ Microhabitat parameters } & & \multicolumn{6}{|c|}{ Dependent variables } \\
\hline & & & \multicolumn{2}{|c|}{ Abundance } & \multicolumn{2}{|c|}{ Size } & \multicolumn{2}{|c|}{ Age } \\
\hline & & $\mathrm{df}$ & $F$ & $P$ & $F$ & $P$ & $F$ & $P$ \\
\hline \multirow{9}{*}{ 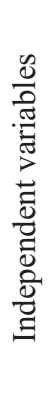 } & Mean site depth & 1.29 & 1.99 & 0.17 & 0.73 & 0.39 & 0.06 & 0.8 \\
\hline & Silt $[\%]$ & 1.29 & 18.56 & $0.0001^{\mathrm{c}}$ & 9.11 & $0.005^{\mathrm{b}}$ & 10.12 & $0.003^{\mathrm{b}}$ \\
\hline & Sand $[\%]$ & 1.29 & 18.47 & $0.002^{\mathrm{b}}$ & 5.2 & $0.03^{\mathrm{a}}$ & 8.53 & $0.006^{\mathrm{b}}$ \\
\hline & Gravel [\%] & 1.29 & 0.28 & 0.6 & 4.89 & $0.03^{\mathrm{a}}$ & 2.11 & 0.16 \\
\hline & Boulders $[\%]$ & 1.29 & 0.64 & 0.43 & 0.7 & 0.41 & 0.79 & 0.31 \\
\hline & Coastal vegetation & 2.28 & 0.7 & 0.5 & 0.66 & 0.53 & 0.73 & 0.49 \\
\hline & Aquatic vegetation & 3.27 & 4.29 & $0.01^{\mathrm{a}}$ & 3.28 & $0.03^{\mathrm{a}}$ & 1.78 & 0.17 \\
\hline & Predators & 1.29 & 0.07 & 0.93 & 8.09 & $0.008^{\mathrm{b}}$ & 10.41 & $0.003^{\mathrm{b}}$ \\
\hline & Bank slope & 1.29 & 3.76 & 0.06 & 3.87 & $0.037^{\mathrm{a}}$ & 1.18 & 0.28 \\
\hline
\end{tabular}

a, b, c Significant at $P \leq 0.05,0.01$, and 0.001 , respectively; $\mathrm{df}=$ degrees of freedom. 
Firstly, the enlargement of sections with sandy bottoms in the littoral zones of excavation lakes led to an increase of suitable breeding habitats for pumpkinseed. Another significant factor is the removal of riparian vegetation along the coast of sand-pit lakes. Reduced shading of riparian zones led to elevation of the littoral temperatures, and while pumpkinseed is able to survive at temperatures over $30^{\circ} \mathrm{C}$ (Gutiérrez-Estrada et al. 2000), these temperatures are extremely disadvantageous for many other fishes. After stopping the exploitation of these lakes, fluctuation of the water level also stops. Additionally, most of these lakes become places for recreational fishing, which puts pressure on the population of native fish species. In this way, human activities facilitate the establishment of pumpkinseed populations, mainly by extending suitable breeding sites for pumpkinseed and eliminating its natural competitors and predators.

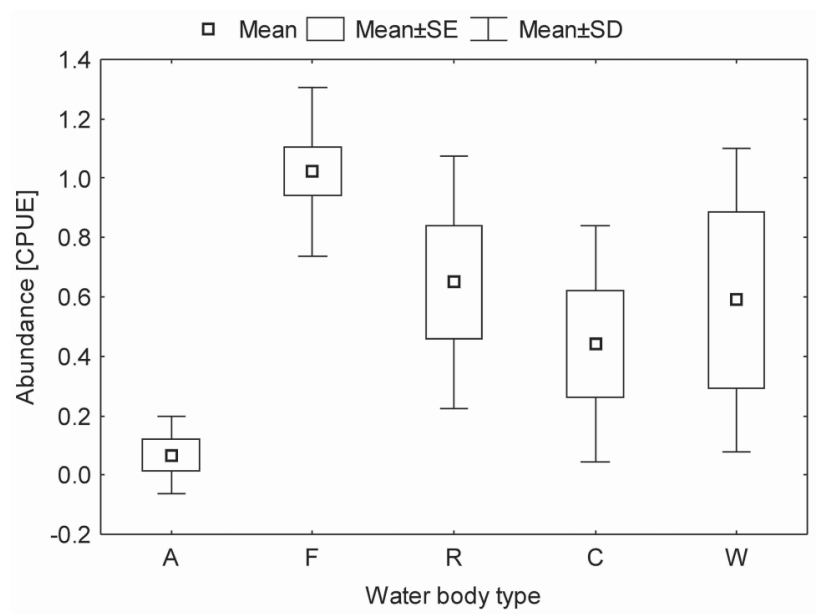

Fig. 5. Relation between abundance $[\log (x+1)$ transformed] of Lepomis gibbosus and the water body use (characteristics); $\mathrm{A}=$ active sand-pit lakes; $\mathrm{F}=$ former sand-pit lakes; $\mathrm{R}=$ reservoirs for irrigation purposes; $\mathrm{C}=$ reservoirs with cage aquaculture; $\mathrm{W}=$ waste water discharge

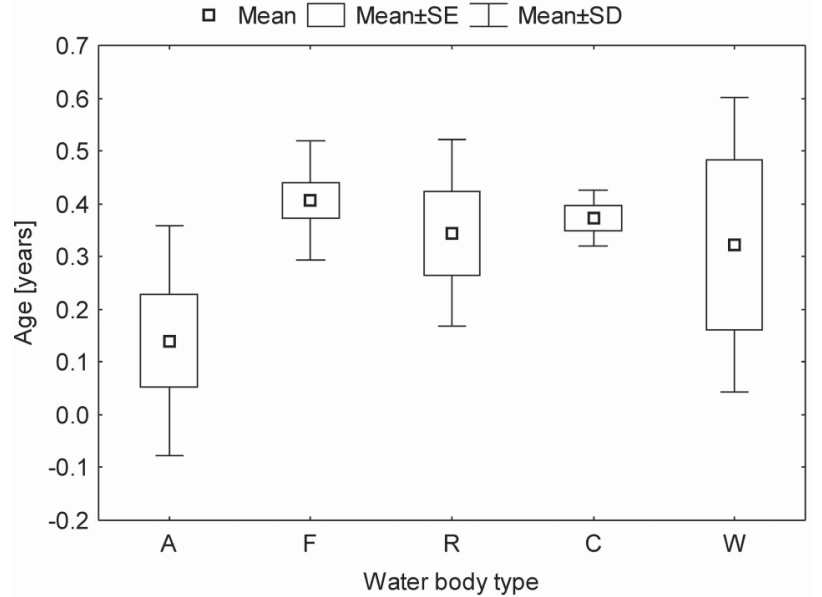

Fig. 6. Relation between age $[\log (x+1)$ transformed] of Lepomis gibbosus and the water body use (characteristics); $\mathrm{A}=$ active sand-pit lakes; $\mathrm{F}=$ former sand-pit lakes; $\mathrm{R}=$ reservoirs for irrigation purposes; $\mathrm{C}=$ reservoirs with cage aquaculture; $\mathrm{W}=$ waste water discharge
The observed fish diversity in the littoral zones of the investigated water bodies was relatively poor. Similar situations were observed in other European water bodies (García-Berthou and Moreno-Amich 2000). Nowadays, there are plenty of factors that could significantly reduce native fish species (unfavourable hydrochemical and hydrophysical conditions, overfishing, invaders, and others). There is no exact answer concerning the extent to which pumpkinseeds have influenced biodiversity and the abundance of native fish species, especially when there are no records from the time before the appearance of pumpkinseeds. We even found that with the growing abundance of pumpkinseeds the species number also increased. It is considered that the communities most vulnerable to L. gibbosus invasion are characterised by low species richness (Moyle and Light 1996, Rahel 2002).

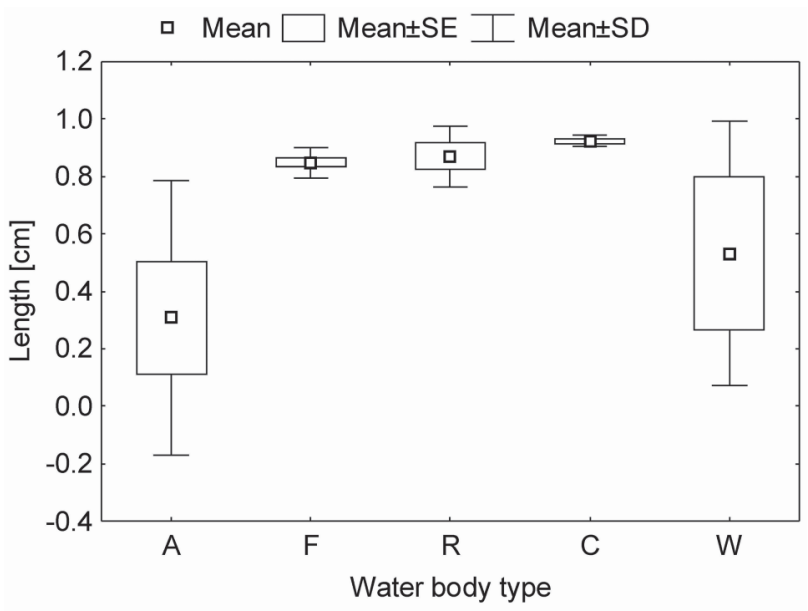

Fig. 7. Relation between total length $[\log (x+1)$ transformed] of Lepomis gibbosus and the water body use (characteristics); $\mathrm{A}=$ active sand-pit lakes; $\mathrm{F}=$ former sand-pit lakes; $\mathrm{R}=$ reservoirs for irrigation purposes; $\mathrm{C}=$ reservoirs with cage aquaculture; $\mathrm{W}=$ waste water discharge

ㅁ Mean $\square$ Mean \pm SE $\perp$ Mean \pm SD

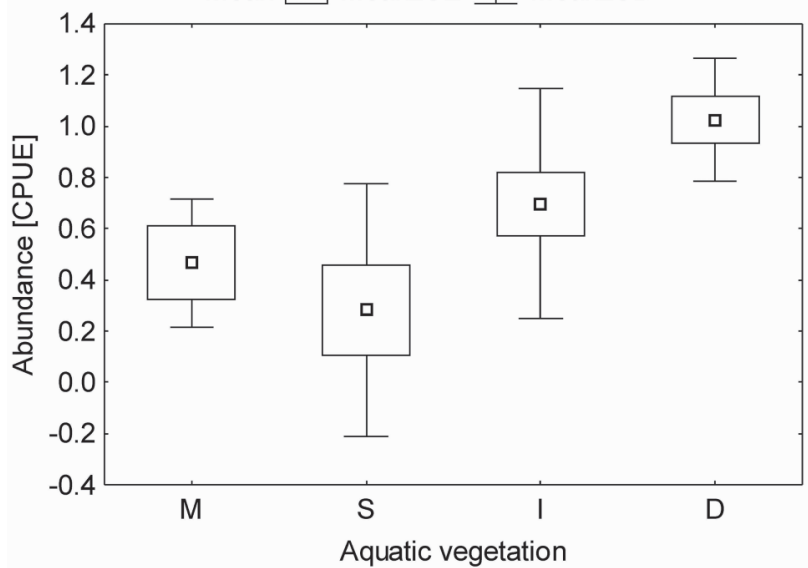

Fig. 8. Relation between abundance of Lepomis gibbosus and type of aquatic vegetation in the littoral zones; Aquatic vegetation: $\mathrm{M}=$ missing, $\mathrm{S}=$ sparse, $\mathrm{I}=$ intermediate, $\mathrm{D}=$ dense 


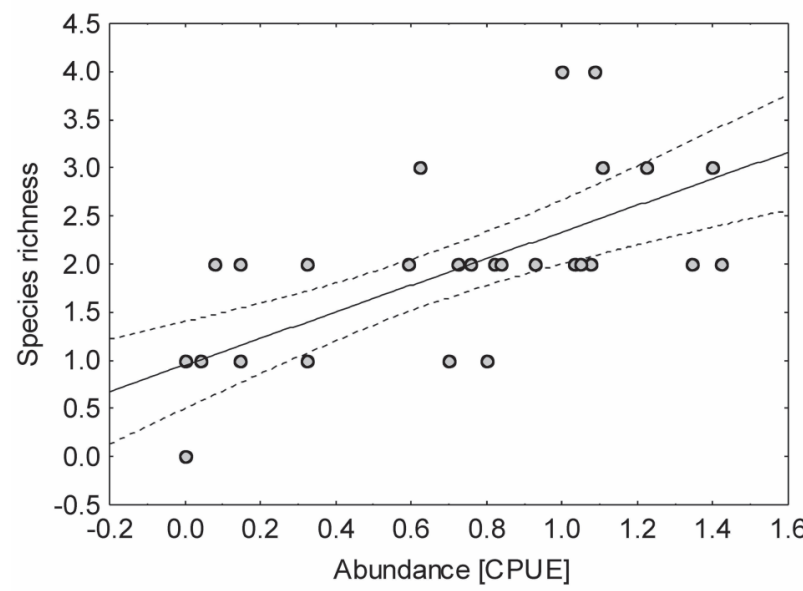

Fig. 9. Regression line of Lepomis gibbosus abundance in relation to the species richness $(\mathrm{CPUE}=$ number of fish per trap per hour)

Even if there is not sufficient contribution to the low abundance and biodiversity, the pumpkinseed managed to use the conditions and to occupy vacant niches and unused resources in the water ecosystem.

The demographic structure of pumpkinseed-inhabited non-native zones of different types of water bodies is influenced by a variety of factors (Copp et al. 2004, Jordan et al. 2009). It is thought that the smaller size and age of the European pumpkinseed populations are a result of the influence of lower mean annual temperatures, limited food resources, and others (Villeneuve et al. 2005). The observed relatively low mean length might be explained by strong intrapopulation dietary overlap or dietary competition with other littoral species (Copp et al. 2004, Klaar et al. 2004). The smallest mean size of pumpkinseeds observed in highly polluted rehabilitation lakes might be due to strongly suppressed development of plankton and benthos. In contrast, in water bodies with a higher level of eutrophication and suitable conditions for the development of trophic resources such as reservoirs with aquaculture activities, pumpkinseeds have larger sizes. The existence of predators in the littoral zone decreased the mean age and size of pumpkinseed in comparison with zones free of predators, but did not influence pumpkinseed abundance.

By revealing the relations between some biological traits and environmental parameters, predictive models could be created to forecast the types of water bodies that are more vulnerable to invasion by alien species. Currently the experience of pest control over the pumpkinseed population is limited (van Kleef et al. 2008). Potentially applicable measures for control could be activities such as manual destruction of the pumpkinseeds' nests, restocking with predator species (e.g., perch and pike-perch), and a simultaneous reduction of the recreational fishing pressure on the native species. In small, shallow water bodies with lower biodiversity, drainage in the summer could be useful. Control over the process of eutrophication by limitation of biogenic elements flowing into the water body through some waste waters and nutri- ent inflow from agriculture and aquaculture has had a positive effect on the reduction of the populations. Some of these activities could be preventative, mainly in uninvaded water bodies. Water bodies inhabited by rare or endangered species should be more strictly controlled. Recreational fisheries should not be underestimated as a vector of introduction through the use of the pumpkinseed as a bait fish (Welcomme 1991, Elvira and Almodóvar 2001, Cambray 2003, Alcaraz et al. 2005, Marchetti et al. 2004, Moyle and Marchetti 2006). With regard to this, fishermen require more information in order to prevent new invasions.

\section{CONCLUSIONS}

The results of the study showed that the variation in the abundance and demographic structure of pumpkinseed corresponded with the type of substrate, density of underwater vegetation and use of the water body. This species finds optimal conditions in former sand-pit lakes and reservoirs where the cage aquaculture activities are well developed, bottom of the littoral zones are covered with sand and submerged vegetation is dense.

It can be concluded that human activities that leads to such alterations of littoral zones and habitat parameters, may be used in the elaboration of prediction models for the risk assessment of different types of water bodies and the potential invasiveness of pumpkinseed.

\section{ACKNOWLEDGEMENTS}

The authors wish to thank to two anonymous reviewers for their helpful comments on the manuscript. The authors would like also to thank Dr. Naidenov from the National Agency of Fisheries and Aquaculture for the assistance in fish sampling in Sopot Reservoir. The investigations were funded by National Scientific Fund (Ministry of Education, Youth and Science, Bulgaria), Grant N 01-0146 /2009-2011.

\section{REFERENCES}

Alcaraz C., Vila-Gispert A., García-Berthou E. 2005. Profiling invasive fish species: the importance of phylogeny and human use. Diversity and Distributions 11 (4): 289-298. DOI: $10.1111 / \mathrm{j} .1366-9516.2005 .00170 . x$

Almeida D., Almodóvar A., Nicola G.G., Elvira B. 2009. Feeding tactics and body condition of two introduced populations of pumpkinseed Lepomis gibbosus: taking advantages of human disturbances? Ecology of Freshwater Fish 18 (1): 15-23. DOI: $10.1111 / j .1600-0633.2008 .00317 . x$

Brabrand E., Saltveit S.J. 1989. Ecological aspects of the fish fauna in three Portuguese reservoirs. Archiv für Hydrobiologie 114 (4): 575-589

Bulgurkov K. 1958. Hidrobiologičeski harakteristiki na ezero Sreb"rna i s"stav na ihtiofaunata. [Hydrological peculiarities of the Lake Srebarna Reserve and its fish composition.] Izvestiâ na zoologičeskiâ institut s muzej. 7: 251-263. [In Bulgarian.]

Cambray J.A. 2003. Impact on indigenous species biodiversity caused by the globalisation of alien recreational freshwater fisheries. Hydrobiologia 500 (1-3): 217-230.

DOI: $10.1023 / \mathrm{A}: 1024648719995$ 
Copp G.H., Bianco P.G., Bogutskaya N.G., Erős T., Falka I., Ferreira M.T., Fox M.G., Freyhof J., Gozlan R.E., Grabowska J., Kováč V., Moreno-Amich R., Naseka A.M., Peňáz M., Povž M., Przybylski M., Robillard M., Russell I.C., Stakènas S., Šumer S., Vila-Gispert A., Wiesner C. 2005b. To be, or not to be, a non-native freshwater fish. Journal of Applied Ichthyology 21 (4): 242-262. DOI: $10.1111 / j .1439-0426.2005 .00690 . x$

Copp G.H., Fox M.G. 2007. Growth and life history traits of introduced pumpkinseed (Lepomis gibbosus) in Europe, and the relevance to its invasiveness potential. Pp. 289-306. In: Gherardi F. (ed.) Biological invaders in inland waters: Profiles, distribution, and threats. Invading NatureSpringer Series in Invasion Ecology, Vol. 2, Part 3. Springer, Berlin.

DOI: 10.1007/978-1-4020-6029-8_15

Copp G.H., Fox M.G., Przybylski M., Godinho F.N., VilaGispert A. 2004. Life-time growth patterns of pumpkinseed Lepomis gibbosus introduced to Europe, relative to native North American populations. Folia Zoologica 53 (3): 237-254.

Copp G.H., Wesley K.J., Vilizzi L. 2005a. Pathways of ornamental and aquarium fish introductions into urban ponds of Epping Forest (London, England): the human vector. Journal of Applied Ichthyology 21 (4): 263-274. DOI: 10.1111/j.1439-0426.2005.00673.x

Crivelli A.J., Mestre D. 1988. Life history traits of pumpkinseed Lepomis gibbosus introduced into the Camargue, a Mediterranean wetland. Archiv für Hydrobiologie 111 (3): 449-466.

Cucherousset J., Copp G.H., Fox M.G., Sterud E. van Kleef H.H., Verreycken H., Záhorská E. 2009. Life-history traits and potential invasiveness of introduced pumpkinseed Lepomis gibbosus populations in north western Europe. Biological Invasions 11 (9): 2171-2180.

DOI: $10.1007 / \mathrm{s} 10530-009-9493-5$

Danylchuk A.J., Fox M.G. 1994. Age and size-dependent variation in the seasonal timing and probability of reproduction among mature female pumpkinseed, Lepomis gibbosus. Environmental Biology of Fishes 39 (2): 119-127. DOI: 10.1007/BF00004929

Drensky P. 1923. Eupomotis gibbous L. edin nov vid v Svišovskoto ezero. [Eupomotis gibbous L. one new fish in Lake Svishtovsko.] Svedeniâ po zemedelieto 11: 6-7. [In Bulgarian.]

Economidis P.S., Dimitriou E., Pagoni R., Michaloudi E., Natsis L. 2000. Introduced and translocated fish species in the inland waters of Greece. Fisheries Management and Ecology 7 (3): 239-250.

DOI: $10.1046 / j .1365-2400.2000 .00197 . x$

Elvira B., Almodóvar A. 2001. Freshwater fish introductions in Spain: facts and figures at the beginning of the 21 st century. Journal of Fish Biology 59 (Suppl. sA): 323-331. DOI: $10.1111 /$ j.1095-8649.2001.tb01393.x

Fox M.G., Crivelli A.J. 2001. Life history traits of pumpkinseed (Lepomis gibbosus) populations introduced into warm thermal environments. Archiv für Hydrobiologie 150 (4): 561-580.

Fox M.G., Vila-Gispert A., Copp G.H. 2007. Life-history traits of introduced Iberian pumpkinseed Lepomis gibbosus rela- tive to native populations. Can differences explain colonization success? Journal of Fish Biology 71 (Suppl. sd): 56-69. DOI: $10.1111 / j .1095-8649.2007 .01683 . x$

García-Berthou E., Alcaraz C., Pou-Rovira Q., Zamora L., Coenders G., Feo C. 2005. Introduction pathways and establishment rates of invasive aquatic species in Europe. Canadian Journal of Fisheries and Aquatic Sciences 62 (2): 453-463. DOI: 10.1139/F05-017

García-Berthou E., Moreno-Amich R. 2000. Food of introduced pumpkinseed sunfish: Ontogenetic diet shift and seasonal variation. Journal of Fish Biology 57 (1): 29-40. DOI: $10.1006 /$ jbi.2000.1285

Gozlan R.E., Britton J.R., Cowx I., Copp G.H. 2010. Current knowledge on non-native freshwater fish introductions. Journal of Fish Biology 76 (4): 751-786. DOI: $10.1111 / \mathrm{j} .1095-8649.2010 .02566 . x$

Gozlan R.E., Newton A.C. 2009. Biological invasions: Benefits versus risks. Science 324: 1015-1016. DOI: $10.1126 /$ science.324_1015a

Gutiérrez-Estrada J.C., Pulido-Calvo I., Prenda J. 2000. Gonadosomatic index estimates of an introduced pumpkinseed (Lepomis gibbosus) population in a Mediterranean stream, using computational neural networks. Aquatic Sciences 62 (4): 350-363.

DOI: $10.1007 /$ PL00001340

Holčik J. 1991. Fish introductions in Europe with particular reference to its central and eastern part. Canadian Journal Fisheries and Aquatic Sciences 48 (Suppl. 1): 13-23. DOI: $10.1139 / \mathrm{f} 91-300$

Jordan C., Backe N., Wright M.C., Tovey C.P. 2009. Biological synopsis of pumpkinseed (Lepomis gibbosus). Canadian Manuscript Report of Fisheries and Aquatic Sciences No. 2886.

Karapetkova M. 1972. Ihtiofauna na reka Ântra. [Ichthyofauna of the Yantra River.] Izvestiâ na zoologičeskiâ institut s muzej. 36: 149-182. [In Bulgarian.]

Karapetkova M., Undzian E.H. 1988. Ihtiofaunata na porečieto na Rusenski Lom. [Ichthyofauna of the Roussenski Lom River.] Hidrobiologia 32: 44-49. [In Bulgarian.]

Klaar M., Copp G.H., Horsfield R. 2004. Autumnal habitat use of non-native pumpkinseed Lepomis gibbosus and associations with native fish species in small English streams. Folia Zoologica 53 (2): 189-202.

Kolar C.S., Lodge D.M. 2001. Progress in invasion biology: predicting invaders. Trends in Ecology and Evolution 16 (4): 199-204.

Kottelat M., Freyhof J. 2007. Handbook of European freshwater fishes. Kottelat and Freyhof, Cornol, Switzerland, Berlin, Germany.

MacRae P.S.D., Jackson D.A. 2006. Characterizing north temperate lake littoral fish assemblages: a comparison between distance sampling and minnow traps. Canadian Journal of Fisheries and Aquatic Sciences 63 (3): 558-568. DOI: 10.1139/F05-240

Marchetti M.P., Moyle P.B., Levine R. 2004. Invasive species profiling? Exploring the characteristics of non-native fishes across invasion stages in California. Freshwater Biology 49 (5): 646-661.

DOI: $10.1111 / \mathrm{j} .1365-2427.2004 .01202 . \mathrm{x}$ 
Marinov B. 1966. V"rhu ihtiofaunata na b"lgarskiâ učast"k na reka Dunav. [On the ichthyofauna of the Bulgarian stretch of the Danube River.] Izvestiâ na zoologičeskiâ institut s muzej 20: 139-155. [In Bulgarian.]

Moyle P.B., Light T. 1996. Biological invasions of fresh water: Empirical rules and assembly theory. Biological Conservation 78 (1-2): 149-161. DOI: $10.1016 / 0006-3207(96) 00024-9$

Moyle P.B., Marchetti M.P. 2006 Predicting invasion success: freshwater fishes in California as a model. BioScience 56 (6): 515-524.

Nikolova M., Uzunova E., Studenkov S., Georgieva M., Pehlivanov L., Velkov B. 2009. Feeding patterns and seasonal variation in the diet of non indigenous fish species Lepomis gibbous $L$. from shallow eutrophic lakes along river Vit, Bulgaria. Natura Montenegria, Podgorica 7 (3): 71-85.

Oliva-Paterna F.J., Andreu A., Verdiell D., Torralva M. 2005. First occurrence of Lepomis gibbosus (L., 1758) in the Segura River basin (SE, Spain). Limnetica 24 (3-4): 199-202.

Panov V.E, Alexandrov B., Arbačiauskas K., Binimelis R., Copp G.H., Grabowski M., Lucy F., Leuven R.S.E.W., Nehring S., Paunović M., Semenchenko V., Son M.O. 2009. Assessing the risks of aquatic species invasions via European inland waterways: From concepts to environmental indicators. Integrated Environmental Assessment and Management 5 (1): 110 -126. DOI: 10.1897/IEAM_2008-034.1

Rahel F.J. 2002. Homogenization of freshwater faunas. Annual Review of Ecology and Systematics 33: 291-315. DOI: 10.1146/annurev.ecolsys.33.010802.150429

Ricciardi A., Rasmussen J.B. 1998. Predicting the identity and impact of future biological invaders: a priority for aquatic resource management. Canadian Journal of Fisheries and Aquatic Sciences 55 (7): 1759-1765. DOI: 10.1139/f98-066

Scott W.B., Crossman E.J. 1973. Freshwater fishes of Canada. Fisheries Research Board of Canada, Bulletin No. 184.

Tandon K.K. 1976. Notes on systematic of the pumpkin seed, Lepomis gibbosus (Ostheichthyes, Perciformes, Centrarchidae). Věstnik Československé společnosti zoologické 40: 307-311.
Tomeček J., Kováč V., Katina S. 2007. The biological flexibility of the pumpkinseed: a successful colonizer through Europe. Pp. 307-336. In: Gherardi F. (ed.) Biological invaders in inland waters: Profiles, distribution and threats. Invading Nature-Springer Series in Invasion Ecology, Vol. 2, Part 3. Springer, Berlin. DOI: $10.1007 / 978-1-4020-6029-816$

Uzunova E., Velkov B., Studenkov S., Georgieva M., Nikolova M., Pehlivanov L., Parvanov D. 2008. Growth, age and size structure of the introduced pumpkinseed (Lepomis gibbosus L.) population from small ponds along the Vit River (Bulgaria). Bulgarian Journal of Agricultural Science 14 (2): 227-234.

van Kleef H., van der Velde G., Leuven R.S.E.W., Esselink H. 2008. Pumpkinseed sunfish (Lepomis gibbosus) invasions facilitated by introductions and nature management strongly reduce macroinvertebrate abundance in isolated water bodies. Biological Invasions 10 (8): 1481-1490.

DOI: $10.1007 / \mathrm{s} 10530-008-9220-7$

Vassilev M. 1999. Changes of ichthyofauna in the Lesenski and the Mazen Marshes (Kamchia Reserve, Bulgaria). Acta Zoologica Bulgarica 51 (1): 57-60.

Vila-Gispert A., Alcaraz C., García-Berthou E. 2005. Lifehistory traits of invasive fish in small Mediterranean streams. Biological Invasions 7 (1):107-116.

DOI: 10.1007/1-4020-3870-4_10

Villeneuve F., Copp G.H., Fox M.G., Stakėnas S. 2005. Interpopulation variation in growth and life-history traits of the introduced sunfish, pumpkinseed Lepomis gibbosus, in southern England. Journal Applied Ichthyology 21 (4): 275-281.

DOI: $10.1111 / \mathrm{j} .1439-0426.2005 .00679 . x$

Welcomme R.L. 1991. International introduction of freshwater fish species into Europe. Finnish Fisheries Research 12: $11-18$.

Received: 14 June 2011

Accepted: 18 May 2012

Published electronically: 30 June 2012 